\title{
FORMULA STUDENT VERSENYAUTÓ TELEMETRIÁJÁNAK FEJLESZTÉSE
}

\author{
Bárány Bence \\ hallgató, Miskolci Egyetem, Automatizálási és Infokommunikációs Intézet \\ 3515 Miskolc, Miskolc-Egyetemváros, e-mail: qgebarbe@uni-miskolc.hu \\ Koba Máté \\ egyetemi tanársegéd, Miskolci Egyetem, Automatizálási és Infokommunikációs Intézet \\ 3515 Miskolc, Miskolc-Egyetemváros, e-mail: autkmate@uni-miskolc.hu
}

\begin{abstract}
Absztrakt
A Formula Racing Miskolc 2013-as megalakulása óta folyamatosan képviseli egyetemünket a Formula Student versenyeken Európa-szerte. Ahhoz, hogy ezt minöségi módon tegyék, az autó fejlesztése állandó kell legyen. Ehhez kapcsolódik a telemetria rendszer megtervezése is. Cikkemben az ehhez kapcsolódó kutatási és gyakorlati eredményeket foglalom össze.
\end{abstract}

Kulcsszavak: telemetria, vezeték nélküli adatgyüjtés, formula student, versenyautó

\section{Abstract}

The Formula Racing Miskolc Racing Team was founded in 2013 and since then the organization has been taking part in various competitions every year across Europe. To maintain the quality, the car's development must be continuous. The telemetry system is related to these improvements as well. In this article you can find the summary of the research and the results connected to the project.

Keywords: telemetry, wireless data acquisition, formula student, racecar

\section{Bevezetés}

Minden modern versenyautó elengedhetetlen kelléke a megbízható telemetria rendszer. Az autók összetettsége és a technika fejlettsége megköveteli, hogy távolról figyelemmel követhetö legyen az egyes paraméterek változása. Profi szinten ez természetesen már mindennapos dolog és enélkül nem is létezik a versenyautó. Esetünkben az autó most ért el egy olyan összetettségi fokot, ami szükségessé tette a telemetria rendszer fejlesztést, így biztosítva lehetőséget a tesztek során az autó megfigyelésére valós körülmények között. Ezzel képesek lehetünk fejlesztési lépcsők ellenőrzésére és akár lehetséges fejlesztési lehetőségekre is felhívhatja a figyelmünket [1].

A fejlesztés megkezdése előtt kutatást kellett végezni különböző piacon kapható rendszerek és más egyetemi fejlesztésű rendszerek összehasonlítása által. Először a piacon jelen lévő késztermékeket vetettük össze. Ezek többnyire professzionális megoldást kínálnak és minimális energiabefektetéssel müködésre bírhatóak közvetlenül beszerzés után. Sajnos azonban az autón párhuzamosan futnak más fejlesztések is, amik lekötik az anyagi erőforrásokat és megkövetelik, hogy minimális költségvetésböl hozzuk ki a legtöbbet minden területen. Számunkra így a saját fejlesztésü rendszer jelenti a költségeink minimalizálását. Mivel az autó kommunikációs protokollja CAN buszt használ, azonban a legtöbb szenzor valamilyen mást, mint például UART, $I^{2} \mathrm{C}$ vagy SPI, így egy olyan eszközt kellett találni, ami ezek mindegyikét képes használni [2]. Emellett a másik fontos szempont a feldolgozó 
egység számítási teljesítménye. Így esett a választás mikrokontroller alkalmazására, ami mind számítási teljesítménye, mind pedig a széleskörü felhasználhatósága miatt kiváló a feladatra.

\section{Gátló pozíció mérés}

Ezen változó ismerete igen fontos az autó menetstabilitásának meghatározásában. Fontos tudni azt, hogy terhelt szituációban a 4 gátló milyen pozícióban van egymáshoz képest. Különböző mérési módszerekkel meghatározható ez a paraméter, de a legegyszerübb, ha egy a gátló mellé beszerelhető mérőeszközt építünk be. Számunkra is ez volt a legkézenfekvőbb megoldás, így egy ilyen eszközt választottunk a kivitelezéshez.

\subsection{A kiválasztott szenzor}

Az eszköz egy speciális kialakítású toló potenciométer, ami megjelenésében megegyezik a gátlóéval. Mechanikai élettartama több mint 25 millió ciklus, megismételhetősége körülbelül $<=0,01 \mathrm{~cm}$, ami rendkívüli pontosságot tesz lehetővé. IP67 szabványú és $-40{ }^{\circ} \mathrm{C}-150{ }^{\circ} \mathrm{C}$ között van a müködési tartománya. A szerkezet egy alumínium házban helyezkedik el, rudazata rozsdamentes acél. Ezekkel a paraméterekkel telemetriai megvalósításokra tökéletes választás. A választott szenzor az 1 . ábrán látható. Kétféle kialakítású is létezik az eszközből. Csapatunknak az ábrán fentebb látható típus áll rendelkezésére, amelyik nem karbonszálas erösítésü.

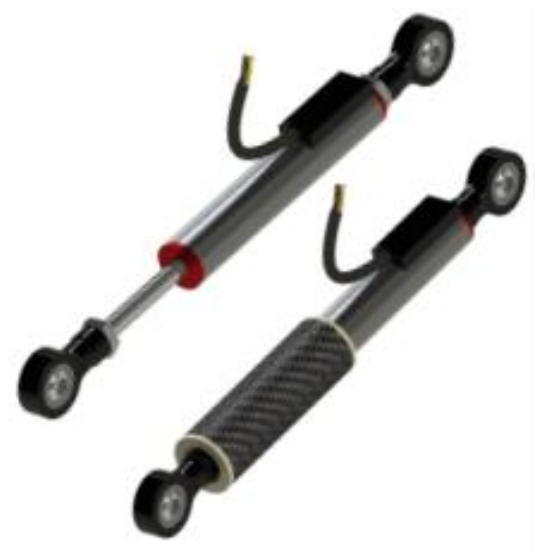

1. ábra. Kiválasztott szenzor [3]

\subsection{Analóg jelek feldolgozása}

A mérést mikrokontroller végzi, ami diszkrét jelekkel dolgozik, azonban mivel valós fizikai mennyiségeket kell mérni, ezért azok időben és amplitúdóban is folytonosak. Ezért valahogyan átalakítást kell végezni a jeleken, ami a mérőeszköz beépített analóg/digitál átalakító áramkörével (továbbiakban ADC) valósítható meg. A különböző típusú jeleket és tulajdonságaikat az 1. táblázat tartalmazza. Láthatjuk, hogy az analóg és digitális jelek mind időben, mind amplitúdóban teljesen eltérnek egymástól, míg az analóg jelek bármelyik időpillanatban bármilyen értéket felvehetnek, addig a digitálisak csak diszkrét időnként, diszkrét értékeket.

$\mathrm{Az}$ analóg/digitális átalakító különálló alrészekböl épül fel, amelyek mindegyike megadott feladatot lát el a jel digitalizálásában. 
1. táblázat. Jelek csoportositása

\begin{tabular}{|c|c|c|}
\hline & Időben folytonos & Időben diszkrét \\
\hline Amplitúdóban folytonos & Analóg jel & Mintavételezett jel \\
\hline Amplitúdóban diszkrét & $\begin{array}{c}\text { Időben folytonos, } \\
\text { amplitúdóban diszkrét } \\
\text { jel }\end{array}$ & Digitális jel \\
\hline
\end{tabular}

\section{Anti-Aliasing szürő:}

Ez gyakorlatilag egy alul áteresztő szürő, aminek nagyon nagy a meredeksége. Nevéből adódik, hogy az Aliasing jelenségtől védi a jelet, ez jellemzően alul vételezett jeleknél fordul elő. Alulmintavételezett jelről akkor beszélhetünk, ha a mintavételi frekvencia nem elég nagy és emiatt látszólagos frekvencia komponensek jelenhetnek meg az átalakításnál. Ezt próbálja kiküszöbölni ez a szürő.

\section{Mintavevő áramkör [4]:}

Feladata, hogy adott pillanatban megnézze a mérendő jel értékét. Ezt ideálisan egy $\delta(t)$ (Dirac-delta) függvénnyel teszi. Ennek a függvénynek a sajátossága, hogy a 0 időpillanaton kívül mindenhol $\mathrm{y}=0 \mathrm{az}$ értéke, de az $\mathrm{x}=0$-ban $\mathrm{y}=\infty$. Ezt tehát egy 0 szélességü végtelen nagyságú jel. A valóságban próbálkoznak a gyártók minél keskenyebb és minél kevésbé zajos tüske impulzust előállítani ennek érdekében. A helyes mintavételnek 2 alapvető tétele van, amelyet Nyquist és Shannon-Kotelnikov tételnek hívnak. Az utóbbi tétel kimondja, hogy a mintavételi frekvenciának legalább kétszer akkorának kell lennie, mint a minta vételezni kívánt jel frekvenciája. Mivel a kétszeres frekvenciájú jellel csak a mintavételezett jel frekvenciája mérhető, érdemesebb nagyobb mintavételi frekvenciát választani, így pontosabb mérés érhető el. Ha ezt nem tartjuk be átlapolódás következhet be a visszaállított jelünkben. Ilyen esetben az eredeti mért érték többé már nem visszaállítható. Az átlapolódási hibára példa a 2. ábrán látható.

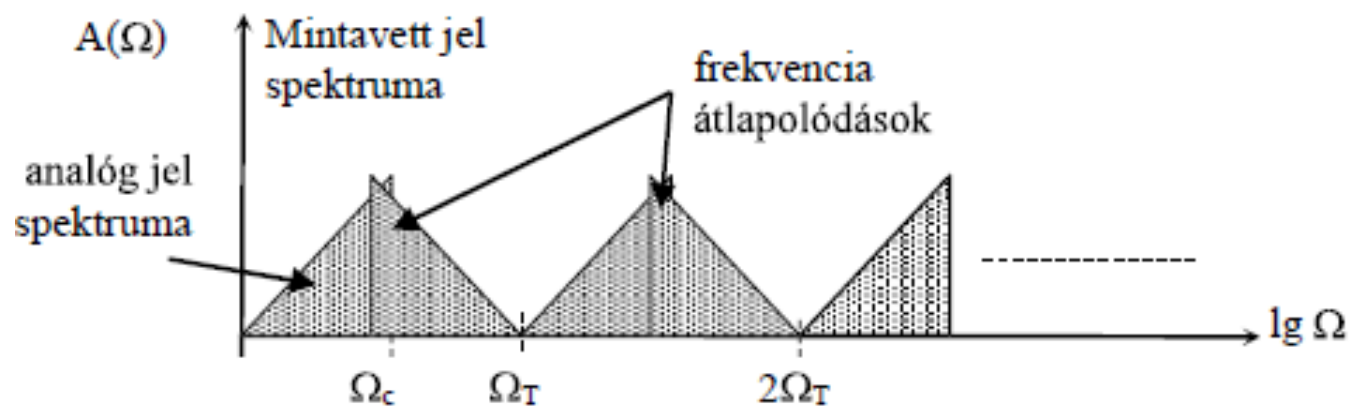

2. ábra. Átlapolódási hiba [4] 
A másik tétel abban segít, hogy a visszaállított jelünk torzításmentes legyen. Ezt egy matematikai módszerrel, interpolációval valósítja meg. Ezek közül a legelterjedtebb a Lagrange-interpoláció módszere.

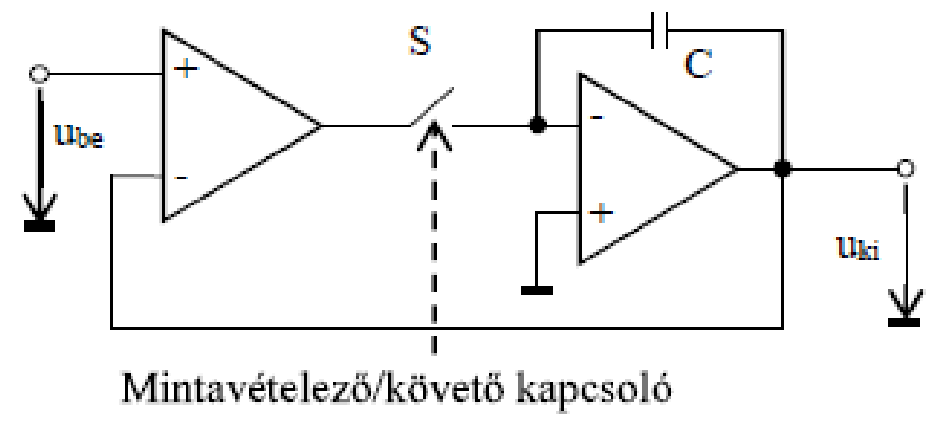

\section{3. ábra. Követö-tartó áramkör [4]}

A mintavételezés legegyszerűbben a 3. ábrán látható kapcsolással valósítható meg, aminek a müködése 2 lépésből áll. Zárt $\mathrm{S}$ kapcsolónál feltöltődik a minta feszültségére a $\mathrm{C}$ kondenzátor, nyitás után pedig tárolja azt. A visszacsatolás az ofszet hiba kiküszöbölésére szolgál. A módszer egyik hibája, hogy a kapcsolás ideje nem lehet soha 0 , ami bizonytalanságot okoz. A másik a kondenzátor tartási ideje, ami ugyan növelhetö a C nagyságával, de abban az esetben viszont csökken a mintavétel dinamikussága, tehát lassul az áramkör müködése.

\section{Kvantáló áramkör:}

Feladata, hogy egyenlö részekre ossza fel az értékkészlet tartományát. Az ADC áramkörök felbontásának is szokták nevezni. 1 felosztást szokás kvantálási lépcsőnek nevezni (q). Számítása: $q=F S / 2^{b}$. A lépcső méretét úgy kell megválasztani, hogy a lehetséges zajok ne legyenek nagyobbak annál, akkor ugyanis könnyedén értékelhetetlen jelet állíthatunk elö.

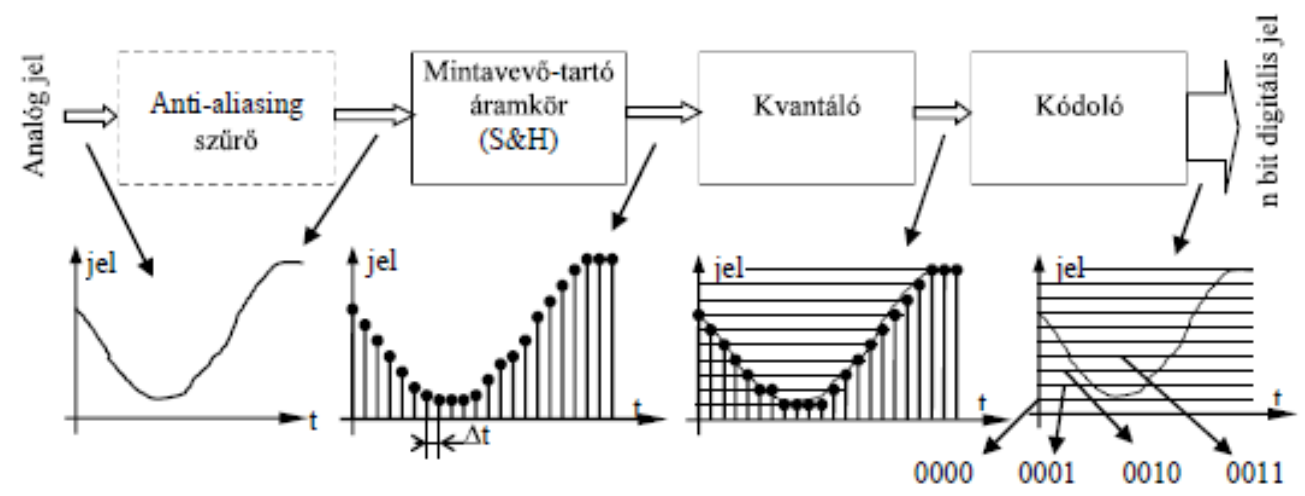

\section{4. ábra. Atalakitás hatásvázlata [4]}

A 4. ábrán az analóg digitális átalakítás egyes lépéseinek hatásvázlata látható. Az ábra jól illusztrálja, hogy az egyes lépések hogyan változtatnak a jelen és összességében hogyan jutunk el az analógtól a digitális jelig. 


\subsection{Felhasznált ADC}

A megvalósításban STM32F103 típusú mikrovezérlőt használunk. A mikrovezérlő belső átalakítója 12 bites felbontású, 16 csatornás egység, amely folyamatos és egylövetű módon is beállítható. Számunkra a folyamatos adatforgalom a megfelelö, hiszen a lehetö legtöbb adatra van szükség a jól értékelhető megvalósításhoz. A tervezésnél figyelembe kellett venni, hogy maximálisan 3,6V és $220 \mu \mathrm{A}$ értékek mellett képes müködni meghibásodás nélkül, illetve, hogy az ofszet hibája 1,5 és 2,5 legkisebb jelentőségü bit (LSB) között van.

\section{Kerékhőmérséklet mérés}

3 szenzor kerül felhelyezésre sorban, egymás mellett, olyan távolságra, hogy a kerék felületét 3 részre osztva mérhessük, így az teljes szélességében láthatóvá válik a szenzorok számára. Összevetve a gátló adatokkal meglehet határozni mekkora stressz éri a gumikat terhelés közben, de az autó körüli áramlásokra is lehet következtetni abból, hogy milyen gyorsan melegszik vagy hül a gumik felülete.

\subsection{Kiválasztott szenzor}

Az MLX90614 családba tartozó szenzorral valósul meg a kerekek hőmérsékletének mérése. A szenzor az 5. ábrán látható. Ez egy kontaktmentes infravörös hőmérő eszköz. Működése Thermopile elven alapul. Autóipari minőségü mérőeszköz, $-40{ }^{\circ} \mathrm{C}-125{ }^{\circ} \mathrm{C}$ tartományban képes $0,14{ }^{\circ} \mathrm{C}$ pontossággal mérni, a teljes tartományra vett pontatlansága pedig körülbelül $1,25^{\circ} \mathrm{C} .2$ vezetékes és 1 vezetékes módszerrel is tud kommunikálni. 1 vezetékes módban PWM jellel, 2 vezetékessel pedig I2C vagy SMBUS protokollon keresztül. A kivitelezés során I2C-n keresztül kommunikáltatjuk, mert így a legegyszerübb a 3 buszba kötött szenzort egymás után elérni.

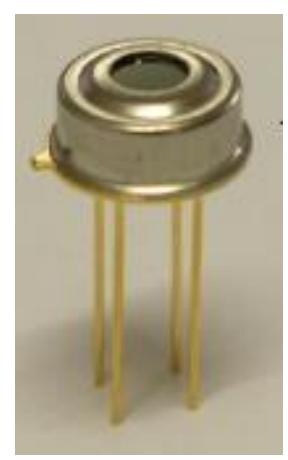

\section{5. ábra. MLX90614 szenzor [5]}

A Thermopile elem úgy müködik, hogy egymással sorba kötött termoelemek melegpontjai közösítve vannak egy infravörös elnyelö anyagban. A hidegpontok egy hütőtömbön vannak közösítve. A közösített elemek száma néhány tíztöl több százig is terjedhet. A hideg és melegpont közötti hőmérséklet különbség feszültséget gerjeszt, ami pedig könnyen mérhető. Hátránya, hogy ez nem egyenesen arányos a hőmérsékletváltozással. Hogy ez egyenes arányosítható legyen, a lehető legtöbb elemet kell sorba kapcsolni egymással és a hidegpontot állandó hőmérsékleten kell tartani. A thermopile elem felépítése a 6 . ábrán látható. 


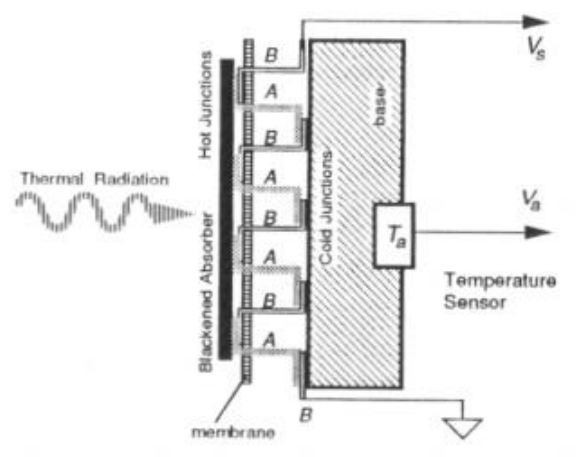

6. ábra. Thermopile elem felépitése [6]

A szenzorban nincsen ugyan megoldva a hidegpont állandó hőmérsékleten tartása, de az érzékelő elem mellé van építve egy jelkondicionáló áramkör, ami a hidegpont potenciálkülönbséget olyan értéken tartja, ami mellett megmarad az arányosság. Viszont ez még mindig analóg jel, amit át kell alakítani, ezért a tokozásba van még integrálva egy 17 bites ADC, ami digitális jelet állít elő a fentebb már említett módszerrel az analóg jelekből. Az I2C kommunikációt egy dedikált digitális jelprocesszor bonyolítja le az eszközök között [7].

Mivel infravörös sugárzás mérésen alapul a folyamat, így fontos szempont a látószög. Ez meghatározza, hogy milyen távolságból milyen érzékenységgel képes mérni az eszköz.

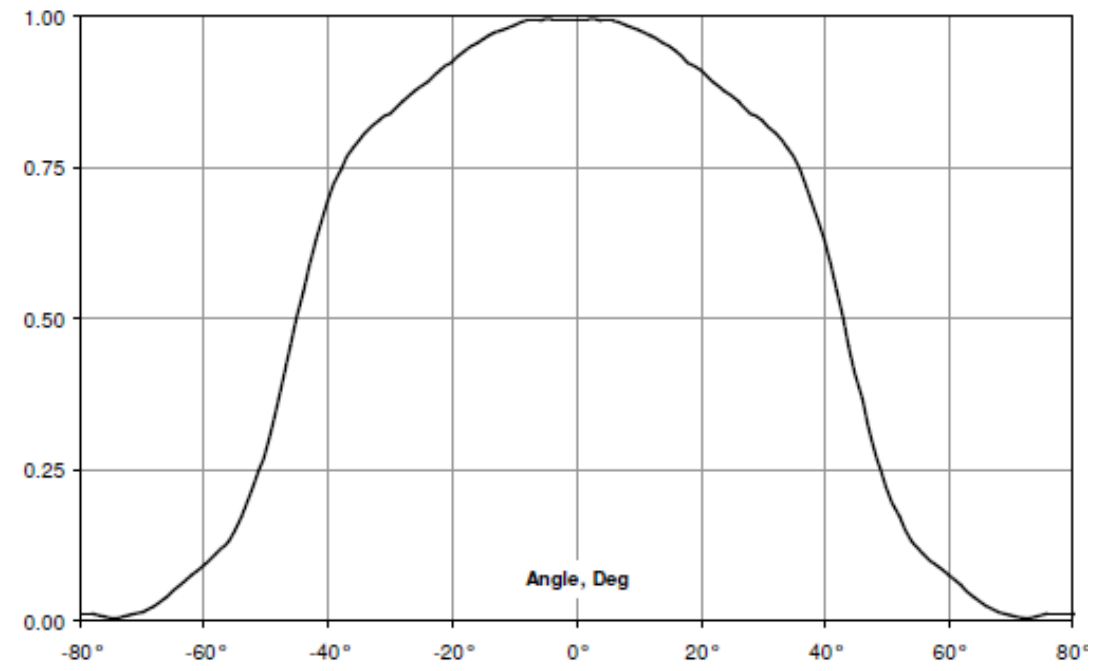

7. ábra. Tipikus látószög [7]

A szenzor látószög karakterisztikája a 7 . ábrán látszik. Erről könnyen értelmezhető, hogy $0^{\circ}$ betekintési szög esetén legnagyobb a pontossága. Ez alapján lett tervezve az autóra a szenzor tartó konzol, a lehető legpontosabb mérés megvalósítása érdekében. Azonban ez még függ a mérés távolságától is. A gyártó által garantált pontosságot maximálisan $8-10 \mathrm{~cm}$ távolságból kaphatjuk, a gyakorlat azonban azt mutatja, hogy inkább $5-8 \mathrm{~cm}$ az ideális. 


\section{Gyüjtött adatok kijelzése}

Az iparban erre nagyon sokféle módszer létezik már. Vannak olyan külön szoftverek, amik akár elöre programozott számításokkal elvégzik az elemzéseket is nekünk. Számunkra azonban a legfontosabb, hogy jól láthatóan egymás mellett jelenítsük meg a kívánt adatokat. Erre a feladatra az STMicroelectornics által fejlesztett STM32 CubeMonitor került kiválasztásra.

\subsection{STM32 Cube Monitor}

Ez a fejlesztőkörnyezet egy másik, széles körben használt kijelző alkalmazáson alapul, a Node-Reden. Széleskörü elterjedése azzal magyarázható, hogy használata bárki számára gyorsan elsajátítható, webszerver alapú alkalmazás, ami azt jelenti, hogy minden azonos hálózaton lévő felhasználó belenézhet a saját eszközén az élő képbe. Használata nagyon hasonló a LabVIEW elgondolásához, előre megírt program blokkokat kell lehelyeznünk, amit utána saját magunknak kell paraméterezni és huzalozni. Ha saját függvényeket akarunk írni, arra is van lehetőség, ezesetben viszont szükséges a JavaScript vagy Node.Js ismerete, ebben viszont a sok felhasználó és az ingyenesen elérhető NodeRed közösség segítséget tud nyújtani.

Az STMicroelectronics ennek alapjára építve készített egy asztali alkalmazást, ami attól lesz jobb, hogy az STM eszközökkel így automatikusan képes kommunikálni bármiféle előkészítés nélkül. Kapcsolatban van a CubeMX-szel és képes érzékelni, ha abban megváltoztatunk valamit, majd ehhez hozzáigazítja magát. Valamint, ha szeretnénk, a processzor diagnosztikáját is képes lekérdezni, amivel például a mikrokontroller áramfelvételét is mérhetjük. Az elkészített grafikus felületet a 8 . ábra mutatja.

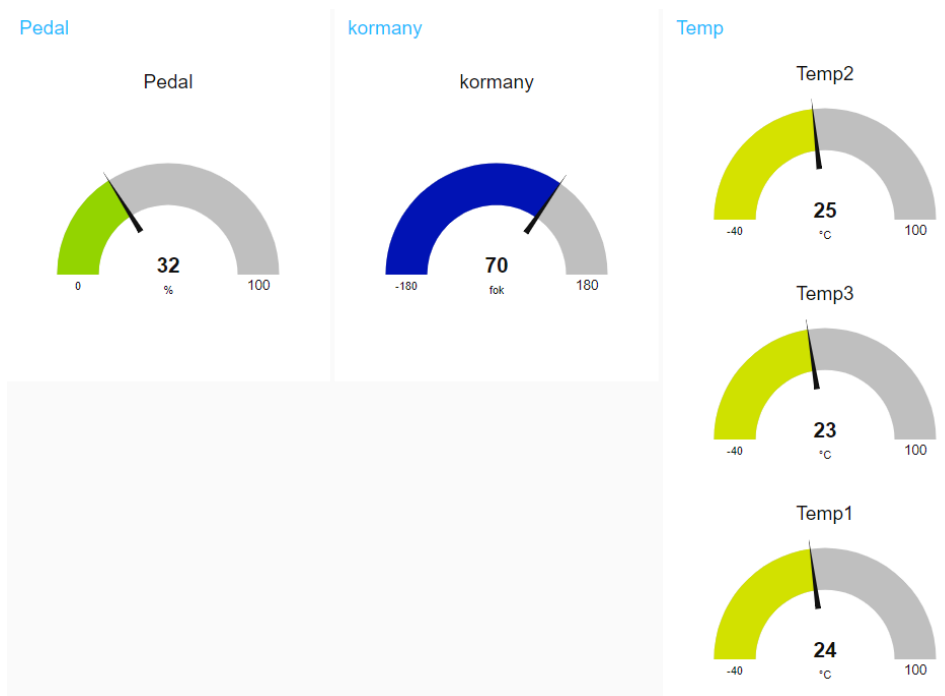

8. ábra. Cube Monitor megjelenitö

\section{5. Összefoglalás}

A kutatás célja, hogy a versenyautó tovább fejlödhessen és a csapat képes legyen folyamatosan elöre haladni. A versenyautót sokféle erőhatás éri használat közben, amiket ismerve fel lehet mérni az autó gyengeségeit és erősségeit is. Emiatt fontos, hogy a tesztek során egy ilyen rendszerrel 
megfigyelhessük az autót. Az információ gyüjtést inkább az olyan paraméterekre összpontosítottuk, amik az autó vezethetőségi problémaira világítanak rá, ezért lettek a kerekek hőmérsékletének és a gátlók pozíciójának a vizsgálata a méréseink tárgyai.

A vírus okozta helyzet miatt a rendszert még nem volt lehetőség terepen kipróbálni, de tesztkörülmények között is derült már fény hibákra és újabb fejlesztési lehetőségekre is. Mivel az időközben elkészült nyomtatott áramkörön felhelyezésre került egy CAN transciever, amellyel rátudunk csatlakozni a motorvezérlő saját hálózatára ezzel lehetőség nyílik még több adat kinyerésére, többek között a beáramló légtömeg és annak hőmérséklete, víz és olaj hőmérséklete, fordulatszám és sebesség...stb. Ezeket szintén belehet illeszteni az adatfolyamba és kiküldeni vagy menteni. Emellett a NYÁK-ra felkerült plusz csatlakozási pontokon illeszteni lehetne a kerék pozíció jeladóit vagy az elektromos kuplung szervójának jeladóját.

\section{Köszönetnyilvánítás}

A cikkben ismertetett kutató munka az EFOP-3.6.1-16-2016-00011 jelü „Fiatalodó és Megújuló Egyetem - Innovatív Tudásváros - a Miskolci Egyetem intelligens szakosodást szolgáló intézményi fejlesztése" projekt részeként - a Széchenyi 2020 keretében - az Európai Unió támogatásával, az Európai Szociális Alap társfinanszírozásával valósul meg.

\section{Irodalom}

[1] Elliot, J. Telemetry helps Formula SAE team close the loop on design-SAE international," Momentum, the Magazine for Student Members of SAE International, 2012.

[2] M. Fathizahed A. Ayaad, ,Telemetry and Data Collection to Improve,” WCECS, USA, 2017.

[3] KA Sensors, „https://www.kasensors.com/” [Online]. Available: https://www.kasensors.com/sites/default/files/downloads/KP94B.012.pdf.

[4] Kovács, E.: Elektronika II, Miskolci Egyetemi Kiadó. 2014.

[5] Melexis Microelectronic Integrated Systems, „MLX9061 family,” 2013.02.28 , p. 1.

[6] Galbács, G.: Analitikai Szenzorok III. Szegedi Tudományegyetem. 2019.

[7] Melexis Microelectronic Integrated Systems, „MLX9061 family,” 2013.02.28. 